\title{
Intraoligochaete development of Myxobolus intimus (Myxosporea: Myxobolidae), a gill myxosporean of the roach (Rutilus rutilus)
}

\author{
Orsolya Z. Rácz, Csaba Székely and Kálmán Molnár
}

Veterinary Medical Research Institute, Hungarian Academy of Sciences, P.O. Box 18, H-1581 Budapest, Hungary

Key words: Myxobolus intimus, myxospore, gill parasite, Rutilus rutilus, intraoligochaete development, Tubifex tubifex, triactinospore

\begin{abstract}
The infection with Myxobolus intimus Zaika, 1965 in the gills of the roach Rutilus rutilus (L.) from Lake Balaton was recorded in 28 out of the 39 fish examined. Developing and mature plasmodia were detected on the gills exclusively in the spring. The Myxobolus intimus infection was found only in 2- to 3-year-old fish. In histological sections, young plasmodia were found in capillaries of the secondary lamellae. More mature, round plasmodia $0.4-0.6 \mathrm{~mm}$ in diameter, deformed the respiratory lamellae. The intraoligochaete development of M. intimus was studied in experimentally infected oligochaetes. In two experiments, uninfected Tubifex tubifex Müller and Limnodrilus hoffmeisteri (Claparède) were exposed to mature myxospores of M. intimus. In both experiments, typical triactinospores developed in $T$. tubifex specimens but no infection was found in $L$. hoffmeisteri. In semithin sections, developmental stages, pansporocysts and actinospores, were found within the proliferated gut epithelium of T. tubifex. Triactinospores were first released from oligochaetes 37 and 58 days after initial exposure in the two experiments, respectively. Each triactinospore had three pyriform polar capsules and a cylindrical sporoplasm with 32 secondary cells. The spore body joined the 3 caudal projections with a moderately long style.
\end{abstract}

The intrapiscine development of myxosporean species is relatively well studied. Knowledge exists primarily on the intrapiscine development of plasmodiumforming species (Noble 1944, Lom and Puytorac 1965, Shulman 1966, Uspenskaya 1984); however, since the life cycle of Sphaerospora renicola became known, many data have been published on species developing in multiple locations (Dyková and Lom 1982, Csaba et al. 1984) as well as on those having the coelozoic type of development (Molnár and Kovács-Gayer 1986, Dyková et al. 1987).

Since Wolf and Markiw (1984) succeeded in experimentally reproducing the developmental cycle of Myxobolus cerebralis, the intrapiscine and intraoligochaete (and occasionally the intrapolychaete) development of numerous myxosporean species has become known. Because of the long duration and difficult execution of the experiments, however, in most cases only the intraoligochaete stage of the developmental cycle was studied and, of the about 27 life cycles known at present, the complete developmental cycle of Myxobolus cerebralis, M. arcticus, M. cultus, M. pseudodispar and Thelohanellus hovorkai has only been elucidated. The majority of experiments have been based on studying a few species of the genus Myxobolus, but data exist on the development of species of Henneguya, Thelohanellus, Hoferellus, Sphaerospora, Ceratomyxa, Zschokkella and Myxidium as well. Studies on the life cycle of Tetracapsuloides bryosalmonae are also at an advanced stage, although the extrapiscine development of this parasite takes place in bryozoans rather than in tubificids. Data on developmental cycles have been summa- rised by Kent et al. (2001). According to the data reported so far, members of the genus Myxobolus form their extrapiscine developmental stages in oligochaete species of larger body size (Tubifex, Limnodrilus, Branchiura, Lumbriculus, Stylodrilus). In experiments conducted in Hungary with Myxobolus spp. (M. drjagini, M. portucalensis, M. hungaricus, M. dispar, M. pseudodispar, M. bramae and M. macrocapsularis) invariably Tubifex tubifex and occasionally Limnodrilus hoffmeisteri served as alternate hosts (El-Mansy and Molnár 1997a, b, El-Mansy et al. 1998, Molnár et al. 1999, Székely et al. 1999, 2001, 2002a, Eszterbauer et al. 2000).

This paper presents new results on the location of plasmodia in the gill of fish hosts and on the intraoligochaete development of the pansporocysts and actinospores of a hitherto little studied myxosporean species, Myxobolus intimus Zaika, 1965.

\section{MATERIALS AND METHODS}

Myxospores of $M$. intimus for infecting oligochaetes were collected from plasmodia developing in the secondary gill lamellae of 2- to 3-year-old roaches (Rutilus rutilus) from Lake Balaton. Altogether 22 roach specimens, $8-17 \mathrm{~cm}$ in length, were dissected in 2002 and 17 in 2003 from the beginning of April to the end of May. In some cases plasmodia were studied fresh, while in other cases the infected gill filaments were fixed in Bouin's solution, embedded in paraffin wax, cut into 4-5 $\mu \mathrm{m}$ thick sections and stained with haematoxylin and eosin (H\&E). Fresh spores collected from matured plasmodia This paper was presented at the 6th International Symposium on Fish Parasites in Bloemfontein, South Africa, 22-26 September 2003. 
were used for experiments. Additionally, the viability of spores was checked by adding spores to a $0.4 \%$ solution of urea. Spores of a given cyst were used for infection when at least $90 \%$ of the spores extruded polar filaments in this solution.

Oligochaetes Tubifex tubifex Müller and Limnodrilus hoffmeisteri (Claparède), identified according to Brinkhurst (1963), were collected from a muddy pool in a forest near the top of a hill in northern Hungary where no fish live. This parasite-free oligochaete stock containing about four times as many T. tubifex as L. hoffmeisteri was transferred to sterilized mud and propagated in the laboratory in aerated aquaria. The worms were fed granulated fish food and were maintained at $19-24^{\circ} \mathrm{C}$. Only laboratory-cultured second-generation oligochaetes were used for the experiments. Laboratory experiments were performed as described by El-Mansy and Molnár (1997a) and Eszterbauer et al. (2000). Tubifex tubifex and L. hoffmeisteri specimens of the original stocks served as controls for the experiments. Uncontaminated tap water was used in each experiment.

The first experiment performed with $M$. intimus was started on 15 April 2002, when an oligochaete stock consisting of about $80 \mathrm{~T}$. tubifex and $20 \mathrm{~L}$. hoffmeisteri specimens was placed into a $500-\mathrm{ml}$ aerated plastic dish containing $200 \mathrm{ml}$ water. About 24,000 spores of $M$. intimus collected from the gills of a 3-year-old roach from Lake Balaton (Tihany) were added. The calculated number of spores/worm was about 240 . On the day after infection, mud sterilized by heat treatment was placed onto the worms in a thin layer, and the dish was filled up with water. The oligochaetes placed into the plastic dish were kept at room temperature $\left(19-24^{\circ} \mathrm{C}\right)$ under aeration; the water evaporating from the dish was replenished regularly, and granulated fish food was added to the mud at weekly intervals to feed the worms. On days 35 and 38 after the first infection, about 30,000 mature myxospores collected from the gills of further two 3-year-old Lake Balaton roaches were poured into the dish.

The second experiment conducted with $M$. intimus was started on 5 May 2003 with 100 million myxospores collected from 3-year-old roaches also originating from Lake Balaton. The calculated number of spores/worm was about 1,000,000. On 5 June, challenge infection was performed with 200,000 spores collected from a roach that had been caught earlier and was kept in an aquarium. Regarding the worm stock and the keeping conditions, the conditions were the same as in the first experiment, although the temperature was 1-2 degrees higher $\left(22-24^{\circ} \mathrm{C}\right)$ than in the previous year because the infection was performed a month later and because the summer was warmer than one year earlier. The temperature values were not recorded regularly.

The water in experimental dishes was regularly filtered through a $21-\mu \mathrm{m}$ mesh. The first filtration was carried out one month after the infection, and the filtrations were repeated twice a week. When actinospores were observed, the worms were immediately washed out from the mud and placed into 2$\mathrm{ml}$ wells of cell-well plates one by one, following the method of Yokoyama et al. (1991). The wells contained clear water up to half their wall height. Before replacing the lid, the plates were covered with self-adhesive plastic foil to prevent the worms from crawling out from one well into another. The plates were kept in refrigerator at $4^{\circ} \mathrm{C}$ throughout the study to maintain the viability of the worms. A thin layer of water from the worm-containing wells of the cell-well plates was checked under a stereomicroscope daily. When actinospores were observed, one drop of water was placed onto a slide and examined with a compound microscope.

In the second experiment the released actinospores were not only checked but also counted regularly. If the number of released actinospores was low (less than 100/well), the number of spores was estimated in the water of the worms under a stereomicroscope, while in the case of a large number of actinospores (more than 100), the spores were counted in a drop of water at low magnification of a compound microscope, and the total number was calculated in relation to the volume of water over the worms. After the triactinomyxons (TAMs) had been harvested above the worms, the water was changed.

The collected spores were photographed with a DH-10 digital camera mounted on an Olympus BH-2 microscope and were recorded also on videotape for subsequent measurement with the help of the IMAGO ${ }^{\circledR}$ computer programme (Székely 1997). Drawings were also made of the spores and their dimensions were recorded. For the morphological characterisation of spores the guidelines provided by Lom et al. (1997) were followed.

In the first experiment, after the cessation of actinospore release, the worms were kept on plates at $4^{\circ} \mathrm{C}$ until their death. However, in the second experiment, after cessation of actinospore release for a few days, the worms were placed back from the plates into sterilized mud kept at room temperature $\left(22-24^{\circ} \mathrm{C}\right)$, and were provided with food again. The water above the oligochaetes placed into the mud was filtered regularly (every 7-9 days) to detect the re-emergence of floating actinospores. When actinospores were detected, the worms were again washed out from the mud, placed onto plates one by one, kept at $4{ }^{\circ} \mathrm{C}$, and examined regularly.

For the semithin section technique, a total of $3 \mathrm{M}$. intimusinfected T. tubifex specimens from the second experiment 74 days after the initial exposure (43 days after the second exposure) were fixed in $5 \%$ glutaraldehyde for $1.5 \mathrm{~h}$ and postfixed in $2 \%$ osmium tetroxide for $2 \mathrm{~h}$, washed several times with sodium cacodylate buffer, dehydrated and embedded in Durcupan ACM resin. Semithin sections $(0.5-1 \mu \mathrm{m})$ were cut and stained with a $0.1 \%$ toluidine blue solution.

For experimental reproduction of the entire life cycle, a total of three experiments were conducted to infect fish with actinospores.

In the first experiment conducted in 2002, five parasitefree, 4- to 7-cm-long fingerlings each of roach Rutilus rutilus (L.), bream Abramis brama (L.), white bream Blicca bjoerkna (L.), orfe Leuciscus idus (L.) and vimba Vimba vimba (L.) were exposed to actinospores released by the worms. For the exposure, the fingerlings were kept together with approximately 10,000 floating actinospores in a 2-litre dish over a period of 4 hours. After exposure in a small volume of water the fish were transferred into aquaria of 40-litre volume. Water temperature during the exposure was $25^{\circ} \mathrm{C}$.

In the second experiment conducted in 2003, 10 roach and 10 white bream fingerlings each were exposed to $40,000 \mathrm{M}$. intimus actinospores. Six hours after the exposure the fish were placed into a 40-litre aquarium where the water temperature was kept at $27-28^{\circ} \mathrm{C}$. 

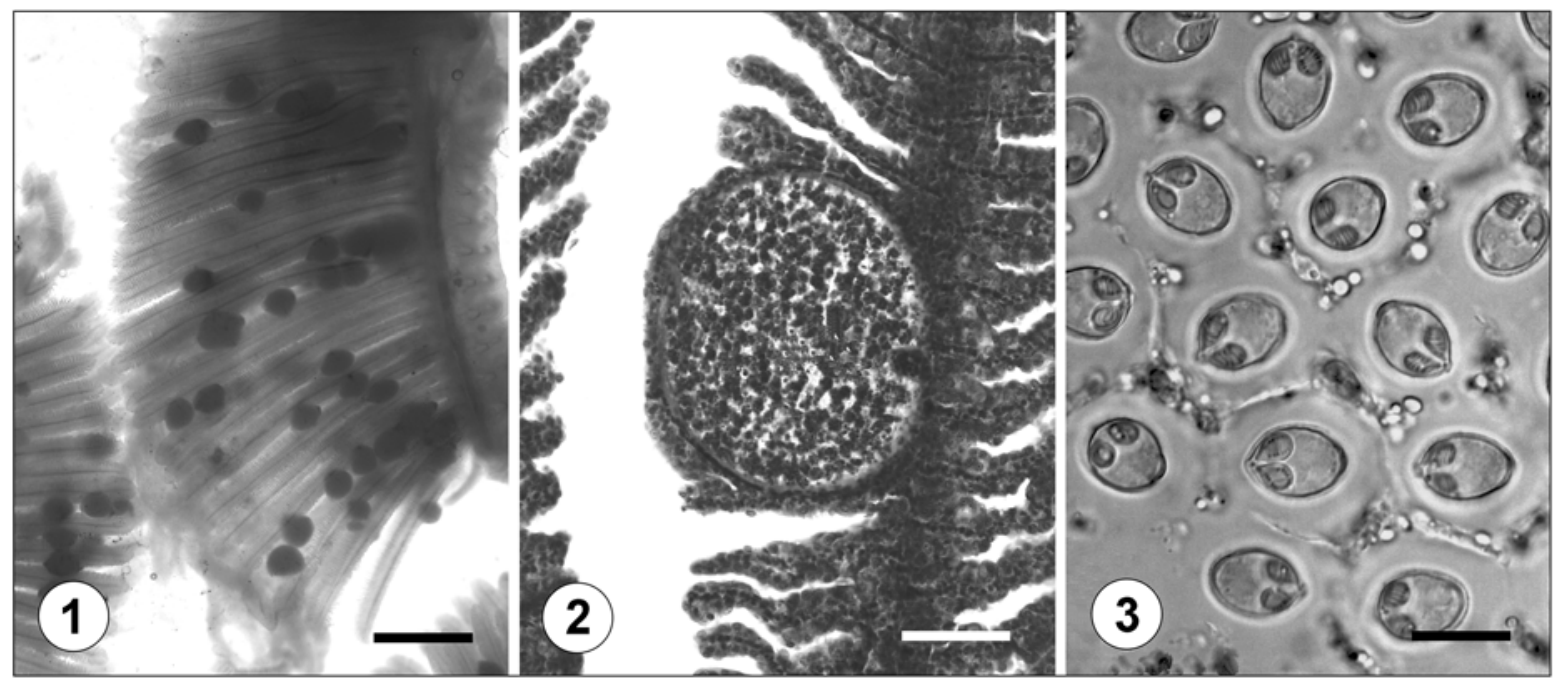

Fig. 1. Typical location of Myxobolus intimus plasmodia in the gill. Fresh preparation. Fig. 2. Myxobolus intimus plasmodium in a secondary gill lamella. The neighbouring lamellae are attached closely to the infected lamella. The rest of the entering artery is still visible. Histological section, H\&E. Fig. 3. Myxobolus intimus myxospores. Spores are surrounded by a thick mucous envelope. Fresh preparation. Scale bars: Fig. $1=2 \mathrm{~mm}$; Fig. $2=0.2 \mathrm{~mm}$; Fig. $3=12 \mu \mathrm{m}$.

During the second experiment, oral infection was also attempted with 10 roach specimens. Before being fed to the fish, the oligochaetes were checked for infection by light microscopic examination on a slide, under a coverslip, in a human manner. To avoid a possible contact infection, the oligochaetes were rinsed with clear water several times before being fed to the fish. Each fish fingerling was placed into a half-litre dish separately, then one massively infected $T$. tubifex was added to each dish; the oligochaete was eaten by the fish within a quarter of an hour. Subsequently, the fish fingerlings were kept in an aquarium where the water temperature was kept at $27-28^{\circ} \mathrm{C}$ with a water heater in the same way as in the previous experiment.

In the first experiment a single fingerling specimen from each fish species was dissected at $8,10,16,28$ and 32 weeks after infection with triactinospores. In the second experiment two specimens of roach and white bream, while two specimens of orally infected roaches were killed at the same dates. The entire gills, the choroid of the eye and the kidney were examined in squash preparations for the presence of myxospores and developing or mature plasmodia.

\section{RESULTS}

\section{Occurrence and development of Myxobolus species plasmodia in roach}

Myxobolus intimus was found in 2- to 3-year-old roach in Lake Balaton. Infection with $M$. intimus in the gills was recorded in 28 out of 39 roach specimens examined in the spring period (the average water temperature was $10.8^{\circ} \mathrm{C}$ in April and $20.1^{\circ} \mathrm{C}$ in May). Before 8 April, only one of the four examined roach specimens harboured infection in the gills. In this fish, developing plasmodia with some young spores were found. From mid-April to mid-May, each of the exam- ined 22 fish proved to be infected with mature plasmodia, while only 5 out of the 13 fish specimens were found to be infected with plasmodia in the gills after 15 May (Fig. 1). In addition to M. intimus infection, intracellular plasmodia of M. pseudodispar Gorbunova, 1936 were found in the muscles of each of the 39 fish examined. In one case, besides $M$. intimus infection, plasmodia of $M$. rutili Donec et Tozyjakova, 1984 were encountered on the gills of roach.

\section{Plasmodial development of $M$. intimus in the fish host}

In histological sections, young plasmodia were found in the capillaries of the secondary lamellae. More mature, round plasmodia $0.4-0.6 \mathrm{~mm}$ in diameter, deformed the respiratory lamellae. Due to the size of the plasmodium, the neighbouring secondary lamellae became flattened and bent back towards the gill filaments (Fig. 2). The stratified epithelium, normally filling the space between the respiratory plates, disappeared. Histologically, it could be observed that the plasmodium was originally located in the capillary network of the secondary lamellae, but in more advanced infection, the plasmodium compressed also the neighbouring lamellae which adhered closely to the wall of the infected lamella. Fully developed plasmodia containing mature spores emerged over the level of the row of the lamellae and protruded into the space between filaments. In some plasmodia the entering artery of the infected lamellae was still discernible.

The plasmodia contained about 11,000 to 18,000 spores. The round or short ellipsoidal spores (Figs. 3, 4) had a characteristic protrusion at the anterior end and a rounded posterior end. In side view the spore had a 

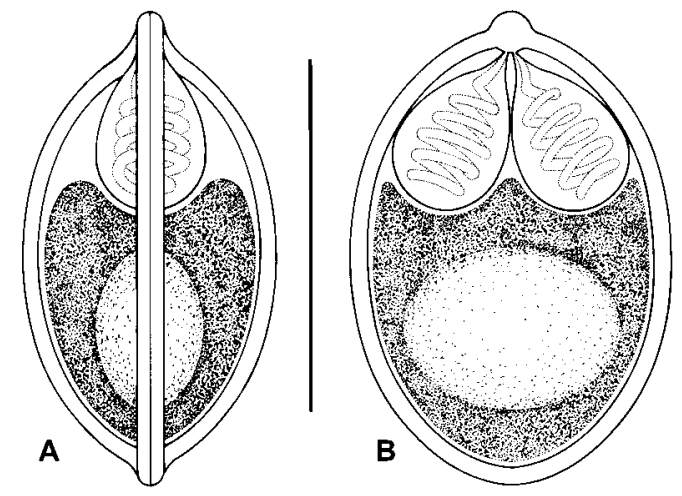

Fig. 4. Schematic drawing of the myxospore of Myxobolus intimus. A - lateral view; $\mathbf{B}$ - frontal view. Scale bar $=10 \mu \mathrm{m}$.

lemon shape with protruding parts of the suture at both ends. The suture was relatively thick, measuring 0.7 to $0.8 \mu \mathrm{m}$. The spores measured $13.5 \pm 0.6(12.6-14.7) \mu \mathrm{m}$ in length, $9.2 \pm 0.4(8.6-9.7) \mu \mathrm{m}$ in width, and $8.0 \pm 0.4$ (7.0-8.5) in thickness (the mean $\pm \mathrm{SD}$, with the range). Pear-shaped polar capsules were equal, measured $5.5 \pm$ $0.4(4.8-6.2) \mu \mathrm{m}$ in length and $3.4 \pm 0.5(2.9-4.8) \mu \mathrm{m}$ in width. Filaments in polar capsules had 5 to 6 turns. The sporoplasm had a well-observable iodinophilous vacuole. Fresh spores released from plasmodia were surrounded by a well-developed mucous envelope.

\section{Intraoligochaete development of $M$. intimus}

In the first experiment performed with $M$. intimus, the presence of floating TAMs in the filtrate of water from the experimental dish was first observed on day 58 after the first exposure to myxospores (Fig. 5). After transferring the oligochaetes into the wells of cell-well plates, 7 T. tubifex out of 96 survived oligochaetes $(7.3 \%)$ proved to be infected. These oligochaetes released actinospores for 15 days starting from the first day of individual examination. Spore release from the seven infected oligochaetes was synchronous. In the course of the 2-month period of observation on the

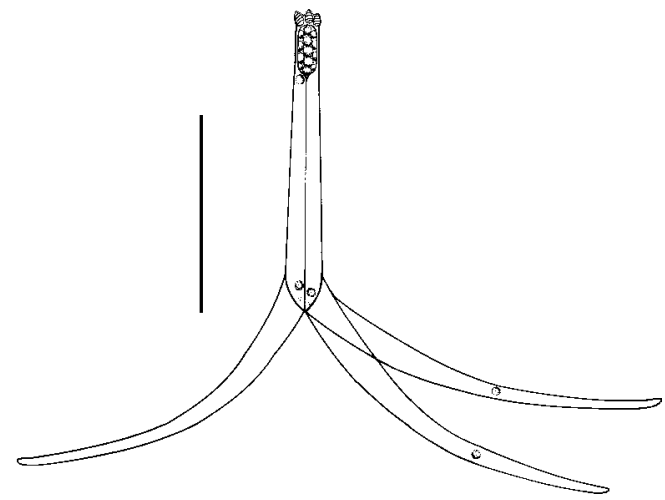

Fig. 5. Schematic drawing of the triactinospore of Myxobolus intimus. Scale bar $=150 \mu \mathrm{m}$.

plates kept at $4^{\circ} \mathrm{C}$, during which the majority of the worms died, no new spore release could be observed.

In the second experiment, the presence of floating TAMs was first observed in the filtrate of water from the experimental dish on day 37 after the first exposure (Table 1). Thirty-two out of 92 oligochaetes (35\%) placed onto the plates and kept at $4{ }^{\circ} \mathrm{C}$ released actinospores. By the 4th day the prevalence increased to $53 \%$ (49 out of 92). Of the two oligochaete species used in the experiment, L. hoffmeisteri did not prove to be infected. Spore release lasted for 7 days, during which period about 77,000 actinospores were released (Table 2 ). Keeping the oligochaetes on the cell-well plates for further 5 days, no further actinospore release was observed. On the other hand, in a stock of oligochaetes placed back from the plates into the half-litre dishes supplied with mud, a new triactinomyxon release was observed 23 days after the last previous actinospore release. These oligochaetes included specimens not used for the oral infection experiment, both those that had stopped releasing actinospores earlier and those that had never released spores. After having been placed on plates again, 80 oligochaete specimens (collected from

Table 1. Temporal release of actinospores under different condition in Experiment 2 (in days).

\begin{tabular}{|c|c|c|c|c|c|c|c|c|}
\hline \multicolumn{2}{|c|}{$\begin{array}{l}\text { Keeping place and keeping temperature of } \\
\text { oligochaetes }\end{array}$} & $\begin{array}{c}\text { Spore- } \\
\text { containing mud } \\
22-24^{\circ} \mathrm{C}\end{array}$ & $\begin{array}{c}\text { Plates } \\
4^{\circ} \mathrm{C}\end{array}$ & $\begin{array}{c}\text { Spore-free } \\
\text { mud } \\
22-24^{\circ} \mathrm{C}\end{array}$ & $\begin{array}{l}\text { Plates } \\
4^{\circ} \mathrm{C}\end{array}$ & $\begin{array}{l}\text { Spore-free } \\
\text { mud } \\
22-24^{\circ} \mathrm{C}\end{array}$ & $\begin{array}{c}\text { Plates } \\
4^{\circ} \mathrm{C}\end{array}$ & $\begin{array}{c}\text { Spore-free } \\
\text { mud } \\
22-24^{\circ} \mathrm{C}\end{array}$ \\
\hline \multicolumn{2}{|c|}{ Duration of keeping in mud or on plates } & $1-37$ & $38-50$ & $51-67$ & $68-95^{*}$ & $96-113$ & $114-135$ & $136-$ \\
\hline \multirow{2}{*}{$\begin{array}{l}\text { First detection of } \\
\text { actinospores from the } \\
\text { water above the mud }\end{array}$} & $\begin{array}{l}\text { Days post first } \\
\text { infection }\end{array}$ & 37 & & 67 & & 113 & & 171 \\
\hline & $\begin{array}{l}\text { Days post second } \\
\text { infection }\end{array}$ & 7 & & 36 & & 82 & & 140 \\
\hline $\begin{array}{l}\text { Duration of spore } \\
\text { release on the plates }\end{array}$ & & & 7 & & 27 & & 13 & \\
\hline Prevalence of infection & & & $\begin{array}{c}53 \% \\
(49 / 92)\end{array}$ & & $\begin{array}{c}71 \% \\
(57 / 80)\end{array}$ & & $\begin{array}{l}17 \% \\
(9 / 53)\end{array}$ & \\
\hline
\end{tabular}

*on day 74 , three worms were fixed for histological examination 


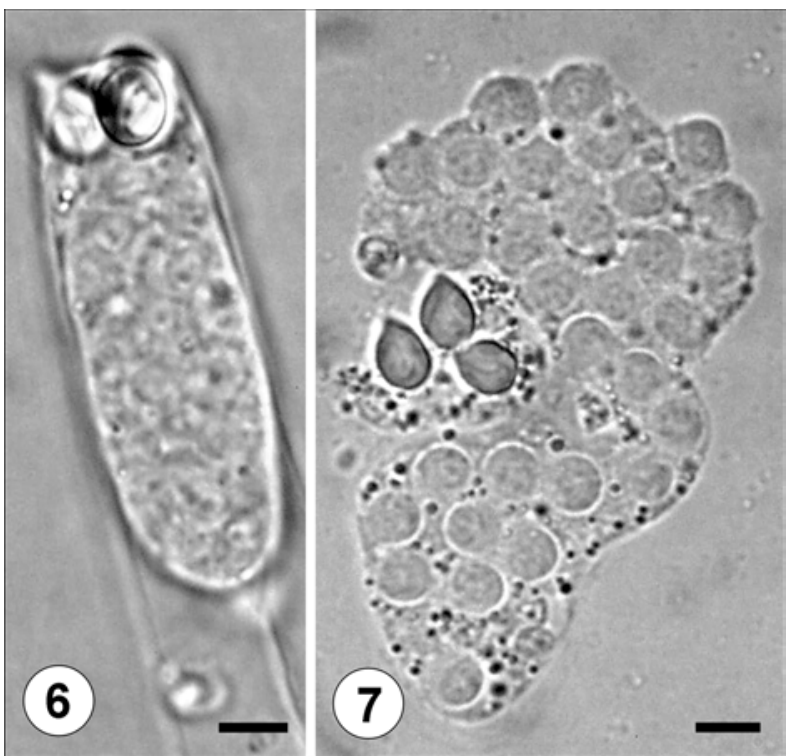

Fig. 6. Spore body of a Myxobolus intimus triactinospore. In the uncompressed triactinospore, a barrel-shaped sporoplasm with less contrasted secondary cells and 2 of the 3 polar capsules at the tip are seen. Fresh preparation. Fig. 7. Inside a ruptured spore body of a $M$. intimus triactinospore, 32 secondary cells with 3 polar capsules are seen. Scale bars: $=5 \mu \mathrm{m}$.

Table 2. Number of actinospores released from oligochaetes during the first, second and third periods screened on plates in Experiment 2.

\begin{tabular}{|c|c|c|c|c|}
\hline & & Period 1 & Period 2 & Period 3 \\
\hline \multirow{12}{*}{$\begin{array}{l}\text { Number of } \\
\text { actinospores } \\
\text { produced on } \\
\text { individual days } \\
\text { of keeping } \\
\text { oligochaetes on } \\
\text { the plate }\end{array}$} & Day 1 & 41,000 & 10,000 & 5,000 \\
\hline & Day 2 & 35,000 & 4,000 & 2,000 \\
\hline & Day 3 & 500 & $-*$ & - \\
\hline & Day 4 & 50 & 1,400 & - \\
\hline & Day 5 & 40 & - & 700 \\
\hline & Day 6 & 10 & 4,000 & - \\
\hline & Day 7 & 10 & 2,200 & - \\
\hline & Day 10 & 0 & 1,200 & 200 \\
\hline & Day 13 & & 500 & 20 \\
\hline & Day 19 & & 200 & 0 \\
\hline & Day 22 & & 70 & \\
\hline & Day 27 & & 5 & \\
\hline $\begin{array}{l}\text { Total number of } \\
\text { released } \\
\text { actinospores }\end{array}$ & & 76,610 & 23,575 & 7,920 \\
\hline
\end{tabular}

*not examined

Table 3. Measurements of Myxobolus intimus triactinospores $(\mathrm{n}=41)$.

\begin{tabular}{|l|l|c|c|c|}
\hline \multicolumn{2}{|l|}{ Dimensions $(\mu \mathrm{m})$} & Mean \pm SD & Min. & Max. \\
\hline \multirow{2}{*}{ Polar capsules } & length & $5.73 \pm 0.56$ & 4.7 & 7.3 \\
& width & $4.09 \pm 0.72$ & 2.9 & 5.8 \\
\hline \multirow{2}{*}{ Sporoplasm } & length & $28.41 \pm 4.31$ & 22.1 & 38.8 \\
& width & $10.18 \pm 1.03$ & 8.3 & 12.3 \\
\hline \multirow{2}{*}{ Spore body } & length & $33.43 \pm 4.27$ & 25.8 & 42.3 \\
& width & $10.67 \pm 1.06$ & 8.1 & 12.7 \\
\hline \multirow{2}{*}{ Style } & length & $158.77 \pm 8.3$ & 144.5 & 176.3 \\
& width & $14.23 \pm 1.5$ & 11.5 & 17.3 \\
\hline \multirow{2}{*}{ Caudal processes } & length & $237.48 \pm 13.94$ & 214.5 & 265.6 \\
& width & $13.06 \pm 1.37$ & 10.5 & 15.8 \\
\hline
\end{tabular}

the mud by washing repeatedly) released triactinomyxons according to the following pattern: $68 \%(54 / 80)$ of these oligochaetes released TAMs on the first day and $71 \%(57 / 80)$ by the third day. Also in this case only the $T$. tubifex specimens proved to be infected. This repeated actinospore release lasted for 27 days, during which period 24,000 spores were released. Following the subsequent few days without actinospore release, the worms again placed into mud produced new TAMs on day 21 (reckoned from the last actinospore release). The remaining 53 Tubifex specimens (less the ones fixed for histological examination), when again washed out from the mud and placed on plates, showed $17 \%$ prevalence of infection $(9 / 53)$ on the first day, which prevalence did not increase subsequently. In this case the spore release lasted for 13 days and the worms released about 8,000 spores in total. After the surviving worms had been placed back into mud at room temperature, TAMs were again observed in the water of the dish on day 43 after the last actinospore release.

Morphologically identical triactinomyxons were released in both experiments. The TAMs of $M$. intimus belong to triactinomyxons of medium size. Their style is rather long, slightly widening towards the caudal projections, and slender rather than robust. The caudal projections are straight or slightly curved, rather long and, gradually tapering, end in a conical tip. They have three pyriform polar capsules and a cylindrical sporoplasm containing 32 secondary cells (Figs. 6, 7). The dimensions of the TAMs are presented in Table 3.

\section{Histological findings}

In semithin sections, actinosporean stages were encountered in the intestinal epithelium of T. tubifex. The epithelium of the worms became enlarged, proliferated and packed with numbers of early actinosporean developmental stages and some pansporocysts containing fully matured triactinospores (Fig. 8). In the spores, three polar capsules and sporoplasm cells were clearly seen, surrounded by pale-staining membranes of the style and caudal processes jammed into a homogeneous mass (Fig. 8 inset, Fig. 9).

\section{Infection of fish with triactinomyxons}

No plasmodial development was found either in roach or in the other cyprinids experimentally infected by $M$. intimus actinospores.

\section{DISCUSSION}

Morphologically, the spores of Myxobolus intimus corresponded to the original description, although their dimensions somewhat exceeded those recorded by Zaika (1965). By the slightly oblique projection at their anterior end, the myxospores of $M$. intimus are well discernible from most Myxobolus species known from cyprinids, but are rather similar to the spores of $M$. obesus (Gurley, 1893) parasitizing bleak (Alburnus alburnus), which have a similar projection, and the 


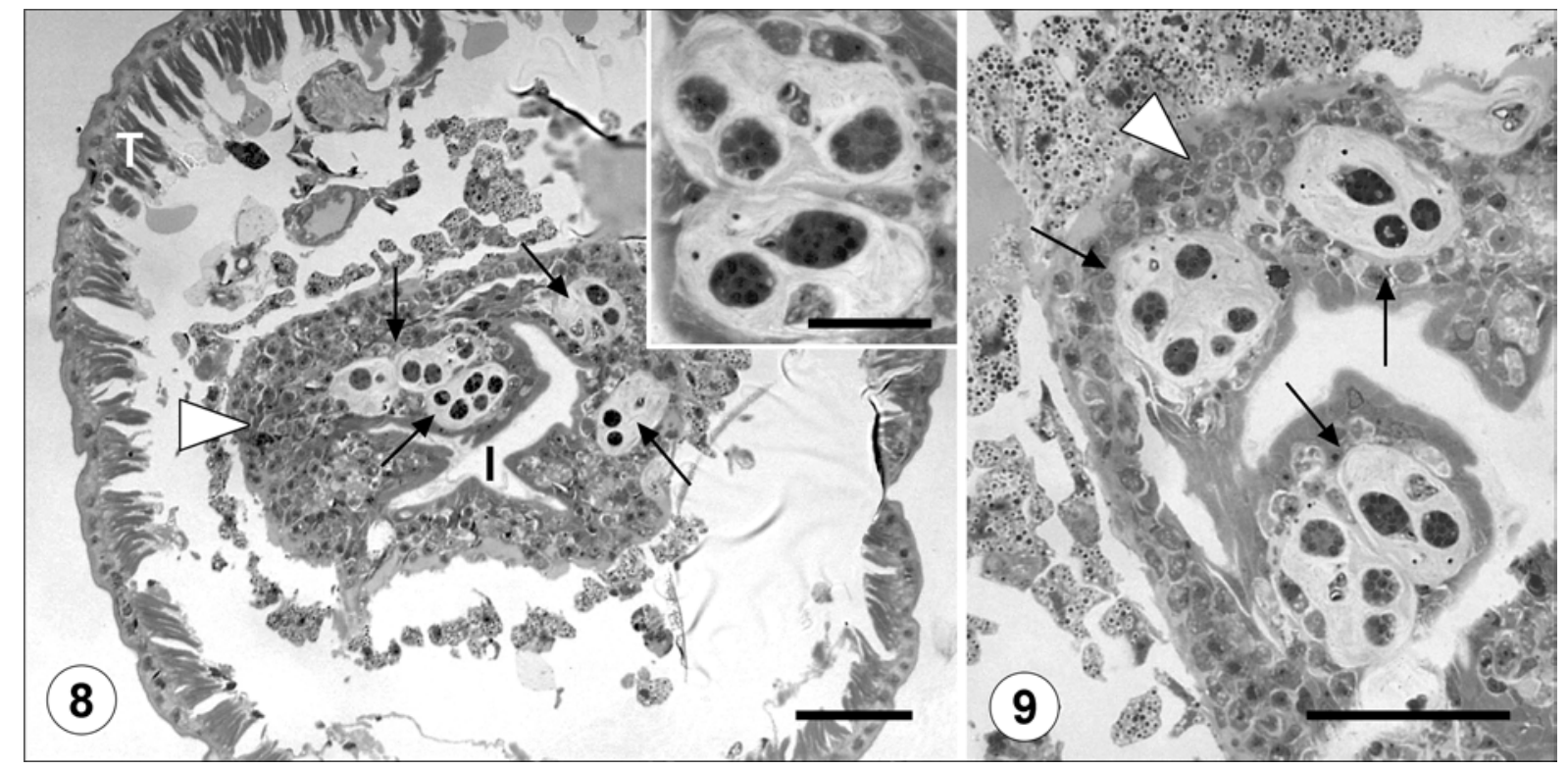

Figs. 8, 9. Cross-section of an infected Tubifex tubifex fixed 74 days after initial exposure to Myxobolus intimus spores. Semithin sections. Fig. 8. Tegument of the worm (T); intestine of the worm (arrowhead); pansporocysts with triactinospores in the intestinal epithelium (arrows); intestinal lumen (I). Inset: Cross-sectioned spore bodies of actinospores inside the pansporocysts surrounded by the pale-staining membranes of the styles and caudal processes of the triactinospores. Fig. 9. The proliferated epithelium of the worm's intestine harbours pansporocysts (arrows) and early stages (arrowhead) of actinosporean development. Scale bars: Figs. $8,9=50 \mu \mathrm{m}$; inset $=20 \mu \mathrm{m}$.

spores of $M$. valdogieli (Dogiel, 1934) parasitic in barbel (Barbus barbus) (Molnár, unpublished). All three parasites form plasmodia in the secondary gill lamellae, but the spores of $M$. obesus and M. valdogieli are smaller than those of $M$. intimus. Certain differences also exist in the seasonality of the parasites, as the spores of $M$. intimus infect fish in April or May, while the plasmodia of $M$. obesus and $M$. valdogieli can be found on the hosts only in May or June. Even by dissecting large numbers of fish, the spores of $M$. intimus could not be detected in roach in other seasons (Molnár et al. 2001).

In the experiments reported here, intraoligochaete development was successful in Tubifex tubifex specimens in both cases. However, as only two oligochaete species were used, it cannot be excluded that intraoligochaete development could be successfully accomplished in other species as well.

Myxobolus intimus forms triactinomyxon-type actinospores in $T$. tubifex alternate host. The morphological characteristics of these triactinomyxons differ from the actinospores of known species originating from cyprinids. The triactinomyxon of $M$. intimus has a much longer style $(159 \pm 8 \mu \mathrm{m})$ than does the actinospore of $M$. bramae $(103 \pm 4 \mu \mathrm{m})$ and its style is several times longer than that of the actinospore of M. macrocapsularis $(60 \pm 3 \mu \mathrm{m})$. In $M$. intimus the caudal projections are much longer $(237 \pm 14 \mu \mathrm{m})$ than those of the actinospore of $M$. hungaricus $(196.7 \mu \mathrm{m})$ and twice as long as those of the actinospores of M. macrocapsularis
$(117 \pm 11 \mu \mathrm{m})$. Both the polar capsule $(7.7 \mu \mathrm{m}$ long $)$ and the sporoplasm ( $39 \mu \mathrm{m}$ long) of the actinospore of $M$. hungaricus are markedly different from those of $M$. intimus (6 $\mu \mathrm{m}$ and $28 \mu \mathrm{m}$, respectively); moreover, the sporoplasm of $M$. hungaricus contains only 18 secondary cells, as opposed to the 32 secondary cells of $M$. intimus (El-Mansy and Molnár 1997b, Eszterbauer et al. 2000, Székely et al. 2002a).

As the basic objective of the present experiments was to identity the actinospore stages of $M$. intimus and to reproduce the developmental cycle, the temperature optima of development, the individual intraoligochaete stages and their duration have not been determined accurately in the given experimental system. The negative results of numerous earlier experiments (unpublished data) indicated that oligochaetes could not be infected successfully with too young or aged spores. For these reasons, about one month after the first infection the oligochaetes were again infected with more mature spores in both of the present experiments. This challenge made the evaluation of the prepatent developmental period uncertain. Monitoring of the process of infection was also hampered by the fact that, to increase the chances of infection, the oligochaetes were not removed from the spore-containing mud until placement on the cell-well plates; thus, it was possible for the oligochaetes to take up spores also long after the time of the first infection. All these factors hampered the exact determination of the prepatent period of intraoligochaete development. 
Different authors usually set the prepatent period of actinospore development between 2 and 4 months. According to El-Matbouli and Hoffmann $(1989,1993)$, the intraoligochaete development of $M$. cerebralis, $M$. cotti and $M$. carassii took 80 to 120 days, while Székely et al. (1998) reported 60 days for Thelohanellus nikolskii and Molnár et al. (1999) 217 days for M. dispar. In the second experiment performed with $M$. intimus, that time proved to be 37 days, indicating that the actinospore development of this species can be accomplished within an extremely short time at the optimum temperature. Although in the first experiment actinospore release first occurred only on day 58, we suppose that already the first infection was successful in both cases. Namely, if only the second challenge infections had been successful, the times elapsing until the appearance of the first actinospores in the water (21-24 days and 7 days in the first and second experiment, respectively) would have proven to be extremely short. The shortening of the prepatent period of the experiment conducted in the second year may have resulted from the faster intraoligochaete development taking place at a temperature $1-2^{\circ} \mathrm{C}$ higher than in the previous year. Whether the repeated spore release and increased prevalence of infection found in the second experiment after placing the oligochaetes back into sterile mud at room temperature (Table 1) can be attributed to the second challenge infection, or rather the developmental stages formed after the first infection produced a late actinospore generation, was not determined. After the third placement of oligochaetes into mud, on day 171 after the first infection, actinospore release was still detectable. This fact indicates that development was not synchronous in the oligochaetes. This is also suggested by the simultaneous presence of actinospore forms of diverse developmental stages in the gut epithelium of oligochaetes, as seen in semithin sections. The effect of temperature on actinospore development has long been known and has been studied in detail by El-Matbouli et al. (1999). Studying Myxobolus cerebralis infection, the above authors have concluded that at a water temperature (5$10^{\circ} \mathrm{C}$ ) below that optimal for the infection of tubifex $\left(10-15^{\circ} \mathrm{C}\right)$, the development of actinospores in the oligochaetes slows down while at a higher temperature $\left(15-20^{\circ} \mathrm{C}\right)$ it becomes faster, but water temperatures exceeding $20^{\circ} \mathrm{C}$ exert an inhibitory or lethal effect on the actinospore stages. Lower temperature is obviously unfavourable for the development of myxosporeans parasitizing cyprinids that require a higher temperature range in the summer vegetation period, and this is why they stopped their spore release in the tubificid worms at $4^{\circ} \mathrm{C}$. At the same time, our experiments also demonstrate that the early actinospore stages do not die in the oligochaetes under adverse temperature conditions; they just arrest or slow down their development and will start to develop again and the release of actinospores will accelerate when favourable temperature conditions are resumed. Differences in the design of experiments and the lack of general knowledge about TAM release prevent a scientifically sound comparison. According to El-Matbouli et al. (1999), worms releasing actinospores released TAMs until the end of the study, i.e. over a period of 64 days, after having been transferred from $15^{\circ} \mathrm{C}$ to $5^{\circ} \mathrm{C}$ temperature. In our study, after transferring oligochaetes from room temperature to $4^{\circ} \mathrm{C}$, actinospore release stopped after 7-27 days and it was not resumed even when the oligochaetes were kept at $4^{\circ} \mathrm{C}$ on cellwell plates for a longer period of time (for 2 months in the first experiment). In our opinion, for the Myxobolus species of cyprinids a temperature of $4^{\circ} \mathrm{C}$ results in a complete arrest of development.

The presence of numerous early development stages seen in histological preparations of worms fixed on day 74 of the second experiment (on day 43 after the second infection) may indicate the success of the second infection; however, it may also indicate infection with myxospores taken up from the mud later or even the asynchronous course of the original infection process. The latter possibility is suggested by the results of Gilbert and Granath (2001), who called attention to the fact that the oligochaete alternate host of Myxobolus cerebralis remains persistently infected throughout its life and can release actinospores almost two years after its infection with myxospores.

The results of the present experiments, primarily those of experiment 2, have also pointed out that the technique used in this study as well as in our earlier studies (Rácz and Timm 2002) may lead to erroneous conclusions. The advantage of placement on plates is that it allows the individual monitoring of the actinospore release of numerous oligochaetes. Keeping the plates at $4^{\circ} \mathrm{C}$ results in longer oligochaete survival than if plates kept at room temperature were used. At the same time, the above approach creates adverse conditions for actinospore formation and thus it is less suitable for estimating the actual prevalence of infection; only the prevalence of infection with mature spores just being released can be determined by its use. Although in the short term the method increases actinospore release, which we attributed to treatment-related stress (washing out from mud, abrupt change of temperature) in the same way as we explained the increased spore release induced by the multifactorial effects of "transportation stress" (Székely et al. 2000, 2002b; Rácz and Timm 2002), it is defective as it arrests the process of development. To replace the keeping of oligochaetes on plates at low temperature and to maintain the viability of experimental oligochaetes, alternative solutions applicable in the future include the method of Gilbert and Granath (2001) who fed oligochaetes with spirulina-disk and that of El-Matbouli et al. (1999) who provided a suitable substrate also under the oligochaetes placed onto plates. 
Unfortunately, we could not infect fish either by contact exposure or per os with actinospores obtained in experiments. Despite the relative long period of observation, plasmodia developing on the gills or in other organs were not formed. Infection of fish with actinospores seems to be a routine task in the case of Myxobolus cerebralis (Wolf and Markiw 1984, Kent et al. 2001), and it can be accomplished with similarly high reliability in the case of Thelohanellus hovorkai, Myxobolus arcticus and M. pseudodispar (Yokoyama 1997, Kent et al. 1993, Urawa 1994, Székely et al. 2001). The unsuccessful attempts can be attributed to several factors. It can be supposed that in the case of species such as $M$. intimus having long, seasonal development, intrapiscine development may be prolonged and require special, variable temperature factors (gradual cooling, cold effect, warming, etc.). However, on the basis of the present experiments it cannot be ruled out either that only a late, possibly overwintered, actinospore generation causes infection in nature. In the roach population studied in Lake Balaton, $M$. intimus infection was observed only in 2-year-old or older fish; therefore, it is not impossible that development can be accomplished successfully only in more mature fish rather than fingerlings used in the present experiments. The existence of a possible abortive infection or of the supposed dormant stages can only be revealed by molecular biological studies to be done in the future, primarily by in situ hybridisation.

Acknowledgements. The study was supported by the Hungarian Scientific Research Fund (OTKA, project nos. T.042464 and T.45891). The authors thank Györgyi Ostoros for her help in the experimental work and Dr. Ferenc Baska for preparing the semithin sections.

\section{REFERENCES}

BRINKHURST R.O. 1963: A guide for the identification of British aquatic Oligochaeta. Freshwater Biological Association Scientific Publication no. 22: 55 pp.

CSABA G., KOVÁCS-GAYER É., BÉKÉSI L., BUCSEK M., SZAKOLCZAI J., MOLNÁR K. 1984: Studies into the possible protozoan aetiology of swimbladder inflammation in carp fry. J. Fish Dis. 7: 39-56.

DYKOVÁ I., LOM J. 1982: Sphaerospora renicola $\mathrm{n}$. $\mathrm{sp}$., a myxosporean from carp kidney, and its pathogenicity. Z Parasitenkd. 68: 259-268.

DYKOVÁ I., LOM J., GRUPCHEVA G. 1987: Pathogenicity and some structural features of Myxidium rhodei (Myxozoa: Myxosporea) from the kidney of the roach (Rutilus rutilus). Dis. Aquat. Org. 2: 109-115.

El-MANSY A., MOLNÁR K. 1997a: Extrapiscine development of Myxobolus drjagini Akhmerov, 1954 (Myxosporea, Myxobolidae) in oligochaete alternative hosts. Acta Vet. Hung. 45: 427-438.

El-MANSY A., MOLNÁR K. 1997b: Development of Myxobolus hungaricus (Myxosporea: Myxobolidae) in oligochaete alternate hosts. Dis. Aquat. Org. 31: 227-232.

El-MANSY A., MOLNÁR K., SZÉKELY C. 1998: Development of Myxobolus portucalensis Saraiva et Molnár, 1990 (Myxosporea: Myxobolidae) in the oligochaete Tubifex tubifex (Müller). Syst. Parasitol. 41: 95-103.

El-MATBOULI M., HOFFMANN R.W. 1989: Experimental transmission of two Myxobolus spp. developing bisporogeny via tubificid worms. Parasitol. Res. 75: 461-464.

El-MATBOULI M., HOFFMANN R.W. 1993: Myxobolus carassii Klokacheva, 1914 also requires an aquatic oligochaete, Tubifex tubifex as intermediate host in its life cycle. Bull. Eur. Assoc. Fish Pathol. 13: 189-192.

El-MATBOULI M., MCDOWELL E.M., ANTONIO D.B., ANDREE K.B., HEDRICK R.P. 1999: Effect of water temperature on the development, release and survival of the triactinomyxon stage of Myxobolus cerebralis in its oligochaete host. Int. J. Parasitol. 29: 627-641.

ESZTERBAUER E., SZÉKELY C., MOLNÁR K., BASKA F. 2000: Development of Myxobolus bramae (Myxospo- rea: Myxobolidae) in oligochaete alternate host, Tubifex tubifex. J. Fish Dis. 23: 19-25.

GILBERT M., GRANATH W. 2001: Persistent infection of Myxobolus cerebralis, the causative agent of salmonid whirling disease, in Tubifex tubifex. J. Parasitol. 87: 101107.

KENT M.L., ANDREE K.B., BARTHOLOMEW J.L., ElMATBOULI M., DESSER S.S., DEVLIN R.H., FEIST S.W., HEDRICK R.P., HOFFMANN R.W., KHATTRA J., HALLET S.L., LESTER R.J.G., LONGSHAW M., PALENZUELA O., SIDDALL M.E., XIAO C. 2001: Recent advances in our knowledge on Myxozoa. J. Eukaryot. Microbiol. 48: 395-413.

KENT M.L., WHITAKER D.J., MARGOLIS L. 1993: Transmission of Myxobolus arcticus Pugachev and Khokhlov, 1979, a myxosporean parasite of Pacific salmon, via a triactinomyxon from the aquatic oligochaete Stylodrilus heringianus (Lumbriculidae). Can. J. Zool. 71: 12071211.

LOM J., MCGEORGE J., FEIST S.W., MORRIS D., ADAMS A. 1997: Guidelines for the uniform characterisation of the actinosporean stages of parasites of the phylum Myxozoa. Dis. Aquat. Org. 30: 1-9.

LOM J., de PUYTORAC P. 1965: Observations sur l'ultrastructure des trophozoites de myxosporidies. C. R. Acad. Sci. (Paris) 260: 2588-2590.

MOLNÁR K., El-MANSY A., SZÉKELY C., BASKA F. 1999: Development of Myxobolus dispar (Myxosporea: Myxobolidae) in an oligochaete alternate host Tubifex tubifex. Folia Parasitol. 46: 15-21.

MOLNÁR K., KOVÁCS-GAYER É. 1986: Observations on the intracellular and coelozoic developmental stages of Hoferellus cyprini (Doflein, 1898) (Myxosporea, Myxozoa) Parasitol. Hung. 19: 27-30.

MOLNÁR K., SZÉKELY C., CSABA G., LÁNG M., MAJOROS G. 2001: Pathological investigations on Lake Balaton fishes II. In: S. Mahunka and J. Banczerowski (Eds.), Results of the Lake Balaton Research in 2001. MTA, Budapest, pp. 160-169. (In Hungarian.) 
NOBLE E.R. 1944: Life cycles in the Myxosporidia. Q. Rev. Biol. 19: 213-235.

RÁCZ O.Z., TIMM T. 2002: First report on the occurrence of actinosporean stages of fish myxosporeans (Myxozoa, Myxosporea) in Estonia. Acta Parasitol. 47: 190-195.

SHULMAN S.S. 1966: Myxosporidia of the fauna of the USSR. Nauka, Moscow, 504 pp. (In Russian.)

SZÉKELY C. 1997: Possible applications of video technology and digital image processing in fish parasitology: morphological examination of the groups Apicomplexa and Myxosporea-Actinosporea by video-technology. Bull. Eur. Assoc. Fish Pathol. 17: 81-82.

SZÉKELY C., El-MANSY A., MOLNÁR K., BASKA F. 1998: Development of Thelohanellus nikolskii (Myxosporea: Myxozoa) in oligochaete alternate hosts. Fish Pathol. 33: 107-114.

SZÉKELY C., MOLNÁR K., ESZTERBAUER E., BASKA F. 1999: Experimental detection of the actinospores of Myxobolus pseudodispar (Myxosporea: Myxobolidae) in oligochaete alternate host. Dis. Aquat. Org. 38: 219-224.

SZÉKELY C., MOLNÁR K., RÁCZ O. 2001: Complete developmental cycle of Myxobolus pseudodispar (Gorbunova) (Myxosporea: Myxobolidae). J. Fish Dis. 24: 461468

SZÉKELY C., RÁCZ O., MOLNÁR K., ESZTERBAUER E. 2002a: Development of Myxobolus macrocapsularis (Myxosporea: Myxobolidae) in an oligochaete alternate host, Tubifex tubifex. Dis. Aquat. Org. 48: 117-123.
SZÉKELY C., SITJÀ-BOBADILLA A., ALVAREZPELLITERO P. 2000: First report on the occurrence of an actinosporean stage (Myxozoa) in oligochaetes from Spanish freshwaters. Acta Vet. Hung. 48: 433-441.

SZÉKELY C., URAWA S., YOKOYAMA H. 2002b: Occurrence of actinosporean stages of myxosporeans in an inflow brook of a salmon hatchery in the Mena River System, Hokkaido, Japan. Dis. Aquat. Org. 49: 153-160.

URAWA S. 1994: Life cycle of Myxobolus arcticus, a myxosporean parasite of salmonid fishes. International Symposium on Aquatic Animal Health, Seattle, 4-8 September 1994. Book of Abstracts, P-W-10.3

USPENSKAYA A.V. 1984: Cytology of Myxosporidia. Nauka, Leningrad, 122 pp. (In Russian.)

WOLF K., MARKIW M.E. 1984: Biology contravenes taxonomy in the Myxozoa: new discoveries show alternation of invertebrate and vertebrate hosts. Science 225: 14491452.

YOKOYAMA H. 1997: Transmission of Thelohanellus hovorkai Achmerov, 1960 (Myxozoa: Myxosporea) to common carp Cyprinus carpio through the alternate host. Syst. Parasitol. 36: 79-84.

YOKOYAMA H., OGAWA K., WAKABAYASHI H. 1991: A new collection method of actinosporeans. A probable infective stage of myxosporeans to fishes from tubificids and experimental infection of goldfish with the actinosporean, Raabeia sp. Fish Pathol. 26: 133-138.

ZAIKA V.E. 1965: [Parasite fauna of fishes from Lake Baikal.] Nauka, Moscow, 106 pp. (In Russian.)

Accepted 2 April 2004 